Jana Pleskalová

Masarykova univerzita

v Brně
UDK 811.162.3'373.231:811.112.2

DOI: 10.4312/linguistica.55.1.149-160

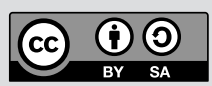

\title{
ČESKO-NĚMECKÉ KONTAKTY VE SVĚTLE ANTROPONYMIE ČESKÝCH ZEMÍ1
}

Česko-německé vztahy a jejich důsledky lze sledovat v dějinách českých zemí již od samých počátků české státnosti (9. - 10. stol.), a to jak v oblasti hospodářské a politické, tak kulturní, společenské i jazykové. V této studii ukážeme, jak se česko-německé kontakty odrážely $\mathrm{v}$ antroponymii českých zemí ${ }^{2}$ (především $\mathrm{v}$ repertoáru křestních jmen) v průběhu 12. - 20. století. ${ }^{3}$ Je třeba zdůraznit, že hlavní prameny výzkumu, administrativní texty obsahující osobní jména, neuvádí údaje o národnosti obyvatel a že německá podoba antroponyma (křestního jména i př́ijmí, ${ }^{4}$ např. Johann Schuster) není jednoznačným svědectvím o jazykové př́íslušnosti pojmenovávaného, nebot' zápisy administrativního charakteru bývaly často prováděny německými písaři, kteří mnohdy křestní jména poněmčovali (Jan > Johann) a sémanticky průzračná česká př́íjmí dokonce překládali (Švec $>$ Schuster). V př́padě smíšených sňatků volili snoubenci někdy prŕjimí české, jindy německé a tyto skutečnosti se promítaly i do volby křestních jmen pro jejich děti; podrobněji Beneš (1998). Proto se při sledování jmen německy mluvících obyvatel soustřed’ujeme na ty oblasti českých zemí, kde bylo německé etnikum v převaze, a z jejich antroponymií pouze na osoby s nečeskou podobou křestního jména (Peter, Petrus) a německým př́jmím (Schwarz).

\section{OBDOBÍ ČEŠTINY 1000-1300}

Z hlediska historického představuje 10. - 13. stol. složité období postupně se formujícího českého státu, který se ve 13. stol. zapojuje do evropského kulturního a politického dění (především středoevropského). Jednotící rámec pro všechny národy západní poloviny Evropy tvořila římskokatolická církev: spojovala středověkou společnost do

* Filozofická fakulta, Ústav českého jazyka, Arna Nováka 1/1, 60200 Brno, Česká republika; pleskalo@phil.muni.cz

1 Studie vznikla v rámci projektu Nový encyklopedický slovník češtiny online - GAP406/11/0294.

2 Termínem antroponymie je označován soubor antroponym $\mathrm{v}$ určitém jazyce, na určitém území a v určité době. $-\mathrm{V}$ našem př́padě se jedná o soubor antroponym obyvatel českých zemí v průběhu 12. -20 . stol.

3 Antroponymický materiál česky mluvících obyvatel čerpáme z monografie Pleskalové (2011).

4 Jako př́ijmí bývá označováno doplňkové neoficiální jméno, a to nedědičné, nezávazné a nestálé.

5 K periodizaci vývoje antroponym viz Pleskalová (2011). 
jednoho celku a do jisté míry „legalizovala“ funkci státních institucí. Její mnišské řády vyjadřovaly dobové ideály zbožnosti a šiřily úctu $\mathrm{k}$ papežství jako instituci nadřazené místním biskupským autoritám. S tímto poselstvím pak mniši pronikali na různá území bez ohledu na suverenitu feudálních vrchností. Z uvedeného vyplývá, že české země měly se svými sousedy, zejména německými, hojné kontakty (podrobněji Beneš 1998, 1:29-33; Rada/Vaníček et al. 1992: 19-97). - Z hlediska jazykového šlo o období, kdy v českých zemích plnila funkci kulturního jazyka latina. První české písemné památky, zpočátku nesouvislé (tj. jednotlivá slova, především antroponyma a toponyma, později části vět a souvětí), pocházejí ve větší míře až od poloviny 12 . stol. Od té doby přibývá písemností, zejména administrativních listin a listů, a s nimi se zvyšuje počet antroponym vypovídajících o obyvatelích českých zemí. I když údaje o jejich „národnosti“ schází (mnohdy máme $\mathrm{k}$ dispozici pouze jméno), poskytuje náš materiál dostatek důkazů o tom, že repertoár antroponym užívaný českými obyvateli vykazuje podobné rysy s repertoárem jmen německých př́íchozích: je to jednak stejný základní repertoár přejatých jmen (viz dále), jednak oficiální jednojmennost: každý člověk byl na veřejnosti identifikován jediným oficiálním jménem (Erkenbertus, Buguslav ${ }^{\diamond}$ ), od konce 12. stol. často provázeným zpřesňujícím doplněním (Slavoň archidiaconus, Engelbertus archidiaconus Bechinensis) nebo (spíše až od 13. stol.) př́imím (Wilhelmus de Dúbravic, Bohuslaus de Horka); citováno podle Pleskalové (2011: 38, 41).

Antroponymie česky mluvícího obyvatelstva se skládá ze dvou stejně závažných částí: 1. Jména domácí, tj. českého, popř. praslovanského původu: Jsou tvořena na základě čtyř obecně platných pojmenovacích motivů antroponym: vyjadřují charakteristiku pojmenovávané osoby na základě některé její vlastnosti (Dobrek 'dobrý člověk'), činnosti (Modlik'k'kdo se modli'), vztah k jiné osobě, bohu (Bogumil 'bohu milý', Vítovic 'syn Vítův'), vztah k místu (Podles). V návaznosti na praslovanštinu se jména tvořila antroponymizací apelativ (často šlo o jména metaforická nebo metonymická: vlk> Vlk), prefixací (Podgrad), sufixací (Budiš < Budivoj) a kompozicí (Väceslav, později Václav 'více slavný').

2. Jména přejatá: Jména německá pronikala do českých zemí v důsledku četných česko-německých politických, hospodářských a společenských kontaktů. Již od 10. stol. je přinášely německé manželky Přemyslovců a jejich početný doprovod (Kunhuta, manželka Václava I.). Proto někteř́ Přemyslovci dostávali německá jména (např. v průběhu 11. - 12. stol. Konrád I. Brněnský a jeho synové Oldřich a Litold, Ota Olomoucký a jeho syn Ota) nebo si je připojovali k českému (Přemysl I. Otakar). V návaznosti na tyto skutečnosti pronikala německá jména také do šlechtických rodů (Oldřich z Hradce, Jindřich z Rožmberka). Na rozšíření německých jmen se dále podíleli němečtí rytiriri, mniši a církevní hodnostáři, napřr. mnozí kněží dostávali při vysvěcení německá jména (sv. Vojtěch převzal jméno svého učitele Adalberta). Př́liv německých jmen vrcholí na konci 13. stol., kdy v rámci velké vnější (německé) kolonizace přichází německy mluvící kolonisté a jejich prostřednictvím se šírí německá jména i do vrstev neurozených: z české země se tak stává země dvou národů se všemi důsledky. Je však

6 Při citaci jsou jména uváděna $\mathrm{v}$ té podobě, jakou mají v př́ślušném historickém pramenu nebo $\mathrm{v}$ odborné literatuře. 
třeba zdůraznit, že němečtí prríchozí (měšt’ané i sedláci) netvořili homogenní skupinu, a to ani po stránce jazykové (mluvili různými dialekty). Brzy se sblížili se svým okolím, ztotožnili se s českou státností a podíleli se na výstavbě země české i moravské jako její plnoprávní obyvatelé (Rada/Vaníček et al. 1992, I: 83-86). Tyto skutečnosti odráží také antroponymie českých zemí, nebot' hojný výskyt německých antroponym je jejím význačným rysem. K nejčastěji užívaným německém jménům té doby patří především Conradus (Cunradus), Heinricus, dále Albertus (Adalbertus), Arnoldus, Bertholdus, Fridericus, Gotfridus, Hermanus, Marquardus, Otto, Odalricus (Ulricus, Oldrich). Druhým, neméně významným zdrojem přejatých antroponym bylo křestanství. Při jeho šíření přicházela do českých zemí - stejně jako tomu bylo v celé západní polovině Evropy - křest'anská/církevní jména řeckého, latinského a hebrejského původu. Uživání těchto jmen se zpočátku omezovalo jen na kláštery a duchovenstvo, ale s rostoucím vlivem mnišských řádů zasáhla české země již ve 13. stol. první vlna křest’anských jmen včetně kultu svatých. Světci se stávají ochránci národa, různých povolání a také těch osob, které nosí jejich jméno. Začínají se prosazovat jména světecká, zatímco jména domácí, pohanská (Nemoj, Črnoch, Vlk apod.) ustupují. Patronem českého národa se stal sv. Václav a jeho zásluhou se české jméno Václav stalo světeckým a zařadilo se v českých zemích mezi nejčastěji užívaná jména církevní. Důležité místo mezi oblíbenými svatými zaujímala ještě babička sv. Václava sv. Ludmila a sv. Vojtěch. K nejčastěji užívaným světeckým jménům patří v první řadě Johannes (Jan) a Petrus (Petr), dále Andreas, Georgius (s českou podobou Jurik), Stefanus, Theodoricus, Martinus, Paulus, Jacobus (podrobněji Pleskalová 2011: 29-36).

Antroponymie německy mluvícího obyvatelstva: Přestože historické prameny té doby o jazykové př́slušnosti pojmenovávaných mlčí, není pochyb, že řada přejatých jmen, která byla zaznamenána v soudobých písemnostech týkajících se českých zemí, patří německým příchozím - šlechtě a duchovenstvu (např. víme, že církevní komunity byly vícenárodní). Jména neurozených lidí byla doložena v této době jen vzácně. Obě etnika (české i německé) spojovalo křest’anské náboženství a s ním i stejná křest'anská jména. Z uvedeného vyplývá, že základní repertoár přejatých jmen církevních i jmen německých byl v obou skupinách obdobný ${ }^{7}$ (o tom svědčí např. jména olomouckých měšt’anů; podrobněji Spáčilová 2011a: 103).

\section{OBDOBÍ 1300-1500}

Etapu hospodářského rozmachu vystř́dalo po roce 1380 dlouhé období hospodářského úpadku. Tehdy zasáhla Království české rozsáhlá morová epidemie, která způsobila zvláště ve městech prudký úbytek obyvatelstva a s ním změnu jeho národnostní skladby. Německé etnikum, které ve velkých městech do té doby převažovalo, utrpělo značné ztráty a na jejich místo nastoupilo české etnikum přicházející z vesnic či málo významných městeček. Tato migrace vedla $\mathrm{k}$ výraznému počeštění měst, ale jen $\mathrm{v}$ Čechách. Na Moravě a ve Slezsku si německy mluvící obyvatelstvo udržovalo převahu

7 Viz výše Antroponymie česky mluvícího obyvatelstva. 
nadále (podrobněji Beneš 1998, I: 31-34). Hospodářský pokles konce 14. stol. ještě více prohloubila husitská revoluce a následné boje o český trůn, které byly ukončeny až v letech 1478-1479. - Národnostní situace je výsledkem předchozího vývoje. V mnohých oblastech českých zemí se na počátku 14. stol. prosadil českoněmecký bilingvismus. I přes pozdější regionální národnostní výkyvy zůstává německé etnikum pevnou součástí obyvatelstva českých zemí. Vedle latiny se $\mathrm{v}$ tomto období začaly ve větší míre uplatňovat také němčina a čeština, a to i v textech administrativní povahy. $\mathrm{S}$ upevňováním pozic českého obyvatelstva $\mathrm{v}$ Praze a ostatních husitských městech se $\mathrm{v}$ 15. stol. začala prosazovat $\mathrm{v}$ městském úr̆adování čeština. Některé administrativní písemnosti byly dokonce překládány do češtiny, a to včetně jejich vlastních jmen, ale existovaly i opačné případy, kdy byly české záznamy (včetně proprií) překládány do němčiny (podrobněji Rada/Vaníček et al. 1992, I: 98-202). Jak české, tak německé etnikum hojně užívalo ve funkci křestních jmen (a později i př́ijmí) formální hypokoristika (Henc < Heinrich, Beneš < Benedikt; podrobněji Spáčilová 2011a: 106-110; Pleskalová 2011: 66-69) a tento trend pokračoval i v dalším období.

Antroponymie česky mluvícího obyvatelstva: Ve funkci oficiálních jmen začínají převládat jména přejatá (příp. jejich hypokoristika), a to jak německá, tak církevní (tj. řeckého, hebrejského a latinského původu), avšak jména domácí (včetně jejich hypokoristik) ještě zcela vytlačena nejsou. V soudobém listinném materiálu vystupují ve funkci oficiálního jména např. jména Bohuslav, Branislav, Dluhomilus, Hlaváč, Jaroš, Mladota, Protivoj, Vlček a ženská jména Př́ba, Sudka, Vojslava (podle Pleskalové 2011: 64-65), ovšem jména vyjadřující charakteristiku pojmenovávané osoby či vztah k místu (Šedivec, Mazal, Hradecký) už mezi nimi téměř nejsou; takto motivovaná antroponyma se totiž přesouvají do sféry neoficiálních pojmenování, stávají se př́ijmím nebo přezdívkou a slouží jako druhé, doplňkové jméno, které bývá stále častěji připojováno ke jménu oficiálnímu (Martin Malý). Tyto dvojice - spolu s dvojicemi oficiální jméno + nepropriální zpřesňující doplnění (Mikuláš mlynár) - vytvářejí základnu, na níž byla postupně budována dvoujmenná antroponymická soustava (křestní jméno + příjmí). Tato dvoujmennost je prozatím neoficiální, nebot' př́ijmí je jméno nezávazné, nedědičné, nestálé, a vztahuje se většinou jen $\mathrm{k}$ mužským zástupcům rodin.

S širrením křestanství se do funkce oficiálních jmen dostávala antroponyma, která byla dávána při křtu, tedy jména křestní. Jejich repertoár představuje plynulé pokračování vývoje antroponym z předchozího období: jeho typickými rysy jsou úbytek domácích jmen a nárůst jmen přejatých: německých (v důsledku česko-německých kontaktů) a církevních (v souvislosti s druhou vlnou křest’anských jmen pronikající ve 14. stol. do českých zemí). Nejčastěji užívaným mužským jménem té doby je Johannes (Johann, Jan), ${ }^{8}$ druhé místo zaujímá Nicolaus (Mikuláš) a o třetí se dělí jména Petrus (Peter, Petr) a Venceslaus (Václav, Wenzel). Vedoucí čtveřici tedy tvoří jména církevní, světecká, z nichž Venceslaus je českého původu a v antroponymii českého etnika hraje významnou roli. Poměrně hojně užívaná jsou též církevní jména Andreas (Ondřej),

8 Podle použitého jazyka mají jména podobu latinskou, německou nebo českou: např. jméno něm. původu Ulrich má lat. podobu Ulricus a čes. Oldřich. Jména jsou dokládána v různých variantách; z nich pro ilustraci vybíráme ty nejčetnější. 
Jacobus (Jakub, Jakob), Martinus (Martin), Mathias (Matyášs, Matěj), Michael (Michal), Paulus (Paul, Pavel), Stephanus (Stephan, Štěpán). Zastoupena jsou také jména Bartoloměj (Bartholomeus), Tomáš (Thomas), Jiř́k (Georgius, Georg), Filip (Philippus). Nejčastěji užívaná ženská jména jsou Margaretha (Markéta), Katherina (Kateřina), Elisabeth (Eliška), Dorothea (Dorota), méně častá jsou Klára (Clara), Ludmila, Magdalena a Jana (Johanna).

Jména německá tvoří rovněž významnou a stabilní část repertoáru křestních jmen. K poměrně často užívaným patří Albert (Albrecht), Bernard (Bernhart), Dietrich (Dětřich), Fredericus (Fridrich, Bedřich), Henricus (Heinrich, Jindřich), Hermanus (Hermann, Heřman), Konrád (Conrad, Kunrád), Ulricus (Ulrich, Oldřich). Mezi častěji užívanými ženskými jmény nebylo žádné německého původu. ${ }^{9}$

Antroponymie německy mluvícího obyvatelstva se i v tomto období shoduje v základních rysech s antroponymií českého etnika a tím dokazuje, jak jsou obě komunity těsně propojené. Nejužívanějším křestním jménem je Johannes v různých podobách (Johann, Hans, Jan, Hensel), o druhé a třetí místo se dělí Nicolaus a Petrus (Peter), poté následují poměrně často užívaná jména Michael (Michel), Jacobus (Jacob), Andreas (Andres), Martinus (Martin), Mathias (Matthäus) a Wenceslaus (Wenzel, ojediněle Waczlaw), nevýznamnější české církevní jméno, jehož nositeli jsou však i v německém prostředí většinou asi Češi. V různé míře a v závislosti na situaci v jednotlivých regionech jsou užívána další církevní jména, jako např. Thomas, Paulus, Franciscus (Francz, Frank), Steffanus (Steffan, Stephan), Georg (Georgius). Ze jmen německých jsou poměrně častá antroponyma Henricus (Heinrich), Albertus (Albert, Albrecht), Hermannus (Hermann), Ulricus (Ulrich), méně častá jsou jména Conradus, Dytmar, Otto, Wilhelm atd. Nejčastějši ženská jména jsou církevní jména Margaretha, Anna, Katharina, Elisabeth, Dorothea, ostatní antroponyma, např. německého nebo českého původu (Kuna, Hedwig, Ludmilla), jsou spíše ojedinělá. ${ }^{10}$

$\mathrm{V}$ antroponymii německého etnika bylo preferováno dvoučlenné pojmenování, tj. křestní jméno/formální hypokoristikum + př́ijmí/přezdívka (Beiname, Übername) Nicolaus dictus Schuster, popř. křestní jméno + dědičné jméno rodiny (Familienname) - Petrus Eberhart, a to i na venkově (Spáčilová 2004; Pleskalová 2011: 87-90). Je tedy pravděpodobné, že německé vyspělejší pojmenovací zvyklosti a zkušenosti s evidencí obyvatel se staly vzorem po obdobné zápisy v českém prostředí.

\section{OBDOBÍ 1500-1786}

Z hlediska historického jde o rozsáhlé a složité období, jehož vylíčení zdaleka přesahuje rámec této studie (podrobněji viz např. Rada/Vaníček et al. 1992, I: 203-303; Bělina/

9 Všechna výše uvedená jména jsou v českých zemích užívána až do 18. stol., ovšem s různým kolísáním dobovým a místním, takže jejich definitivní pořadí podle četnosti jejich výskytu sestavit nelze. Toto tvrzení platí pro všechny soubory užívaných jmen v této studii uvedených. Podrobněji Pleskalová (2011: 63-66).

10 Prameny: Horčička (1896); Müller (1929); Schlesinger (1892); Spáčilová (2011a: 103-104); Spáčilová (2011b: 427-430). 
Rak et al. 1992, II: 11-56). Pro antroponymii té doby je důležitý fakt, že první př́ílušník „,cizí“, tj. habsburské dynastie byl uveden na český trůn v r. 1526 a od té doby až do r. 1918 byly české země nedílnou součástí většího státního celku se všemi důsledky, $\mathrm{k}$ nimž patřil také př́iliv cizinců (urozených i neurozených), a to především Němců (Beneš 1998: 34-51). - Z hlediska vývoje antroponymie českých zemí je však tato etapa českých dějin pojímána jako jeden celek, nebot' jejím nejvýraznějším rysem je neoficiální dvoujmennost (v rámci německého etnika jde již o poměrně stabilní dvoujmennost), která byla definitivně ukončena patentem Josefa II. z 1. 11. 1786, nařizujícím obyvatelům dědičných zemí přijmout stálé př́ijmení. Pro židovské obyvatelstvo vešlo toto nařízení v platnost od 1.1.1788 (Pleskalová, 2011: 94-95).

Antroponymie česky mluvících obyvatel: Typickým rysem je neoficiální dvoučlenné jméno (křestní jméno + př́ijmí), které se postupem doby prosazuje a ustaluje, takže před r. 1786 měl téměř každý mužský zástupce rodiny toto dvoučlenné, poměrně ustálené jméno (Martin Šimek). Nedospělé děti a ženy nadále zůstávaly při identifikaci vázány na otce či manžela (Anna dcera Hanušova, Anna manželka Šimkova, ale i Anna Šimkova).

Repertoár mužských jmen se do r. 1720 nijak podstatně nemění, obsahuje především jména oblíbená $\mathrm{v}$ předchozích obdobích. Nejužívanějším křestním jménem $\mathrm{v}$ českých zemích nadále zůstává Jan (Johannes, Johann), velmi časté bývá v některých regionech i jméno Jiří (Jiřik, Georg, Jíra). Mezi často užívaná jména patří Martin (Mertl), Václav (Wenzl, Vaněk), Pavel (Paul), Matěj (Mates), Matyáś (Mathias), Jakub (Jakob), Havel, Matouš, Ondřej (Andreas, Vondra), Jindřich (Heinrich, Jindra), Tomáš (Thomas, Tomeš), Vitek (Vit), Daniel (Daněk), o něco méně jsou zastoupena antroponyma Petr, Mikuláš (Nicolaus, Niklas), Šimon, Štěpán (Steffan), Urban, Bartoloměj (Bárta, Bartl), Vavřinec (Lorenc, Vávra), Řehoř (Gregor, Říha), Valentin, Blažej (Blažek), Bedřich, Karel, Adam, Marek, Kliment, Michal (Michael), Kryštof, Tobiáš (Dobiášs), Kašpar, Lukáš (Lucas, Lukeš), Zikmund (Sigmund), Bernard, Vojtěch. Jméno Františsek se častěji vyskytuje v podobě Franz, a to většinou v oblastech, kde sídlili i Němci.

\subsection{Repertoár ženských jmen do roku 1720}

K nejoblíbenějším patří Anna, Kateřina, Dorota a od druhé poloviny 17. století je v některých oblastech patrný nárůst jména Marie, a to patrně - vedle světice Marie Magdaleny - již jako důsledek cílevědomě pěstovaného mariánského kultu. Často užívaná jsou antroponyma Ludmila (Lidmila), Magdalena (Mandalena), Alžběta (Elisabeth), Markéta (Margareta, Margita, Margeta, Markyta), Kunhuta (Kuna), Zuzana (Zuzka), Mariana, Apolena, Barbora, Salomena, o něco méně jsou zastoupena jména Alina, Justina, Uršula (Voršila), Regina, Marta, Polyxena, Johana, Maruše, Františka.

Tento základní soubor mužských a ženských křestních jmen doplňuje množství sporadicky užívaných antroponym různého původu (např. Ambrož, Benjamin, Ctibor, Florián, Jeroným, Jonášs, Augustina, Juliana, Lukrécie) a společně vytváří pestrý a bohatý repertoár křestních jmen, který se v jednotlivých oblastech - podle konkrétních podmínek - mírně obměňuje. Např. mnohá ze jmen považovaných v celoúzemním mě- 
řítku za málo uživaná či sporadická mohla z různých příčin dosáhnout v některých regionech vyššího výskytu. Výběr křestních jmen je totiž ř́zen určitými pojmenovacími motivy a míra jejich uplatnění závisí na konkrétní situaci v dané oblasti. Např. Holá (2009: 191) zjistila, že za nadprůměrnou oblibou jména Karel ve vsi Janovice stojí místní primas téhož jména, který býval vyhledávaným kmotrem, po němž děti obvykle dostávaly jméno. Nově narozeným dětem byla také často volena jména podle patrona místního kostela nebo prríslušného regionu (Wolfgang na Klatovsku).

\subsection{Křestní jména v 18. století}

Repertoár těchto jmen prošel v 18. století výraznými změnami. Vyvolaly je 1) zvýšený kult P. Marie a sv. Josefa (jméno Ježís je dodnes v České republice tabu), 2) kanonizace nových svatých a jejich propagace církevními rády (František Xaverský, Jan Nepomucký, Karel Boromejský, Antonín Paduánský, Terezie atd.), 3) využití těchto jmen v Habsburském rodu (Marie, Terezie, František, Josef, Karel...). Dříve užívaná křestní jména sice nezanikla, užívala se dále (byla podporována rodinnou tradicí, různými aktuálními potřebami a místními zvyklostmi), ale v popředí stála již nová jména, označovaná jako barokní; podrobněji Šmilauer (1974: 20-25); Pleskalová (2011: 97-107).

\subsection{Mužská jména}

K nejoblíbenějším jménům patří v první řadě Jan (Johannes, Johan, Hans), jehož popularita byla podpořena kanonizací Jana Nepomuckého (1729), dále Josef, František (Franz), Václav (Wenzl) jako patron českých zemí, v některých oblastech má vysokou četnost též Antonín (Anton). Mezi běžně užívaná se řadí Jakub (Jakob), Matěj, Jiř̌́, Karel, Šimon, Kašpar, Martin, Ondřej, Vojtěch, Tomášs, Matouš, Michal, Ignác, Dominik, Petr, Adam, Bartoloměj, Pavel, Daniel, Leopold, Joachim, Vavřinec (Lorenc).

\section{4 Ženská jména}

Nejvíce oblíbená jsou jména Marie, Anna, Kateřina, často užívaná jsou antroponyma Barbora, Josefa, Dorota, Magdalena, Františka, Eva, Terezie, Alžběta, Ludmila, poměrně častá jsou Markéta, Rozina, Zuzana, Jana (Johana), Veronika.

Tento základní repertoár mužských i ženských křestních jmen doplňuje řada antroponym užívaných jen sporadicky (viz např. Beneš 1998, I). Dodejme, že mezi oblíbenými jsou pouze dvě jména německého původu (Karel, Leopold), zato tři jména domácí - česká (Václav, Vojtěch, Ludmila).

\subsection{Antroponymie německy mluvících obyvatel}

Vyvíjí se ve stejných podmínkách jako antroponymie českého etnika, proto v ní od začátku 18. stol. zaujímají čelné místo jména barokní (viz výše). Antroponyma, která patřila k oblíbeným jménům v 17. století., sice z užívání nevyšla (jejich zásluhou je repertoár křestních jmen nadále pestrý), ale jejich četnost klesla. Např. Spáčilová 
(2011a) uvádí, že v Olomouci byl v 16. - 17. stol. nejoblíbenějším mužským jménem Johann, na druhém místě byl Georg a po něm následovala antroponyma Martin, Mathias/Matthäus, Jacob, Wenzel, Valentin, Andreas, Paul, Christoph. Méně častá, ale dokládaná z celého zkoumaného území byla jména Albrecht, Andreas, Elias, Fridrich, Gregor, Hans (<Johannes), Casper, Urban, Wenzel (viz např. Rozprýmová 2007; Kloudová 2011). Z ženských jmen se nejvíce uplatňovala Anna, dále Barbara, Magaretha, Marina, Katharina (podle Spáčilové, 2011b: 428) ${ }^{11}$. - Jak v českém, tak v německém prostředí mohly děti dostat při křtu dvě jména: Jan Václav, Johann Adolf, Anna Marie.

V 18. století došlo v repertoáru křestních jmen $\mathrm{k}$ výrazným změnám. Také v německém prostředí ovlivňovaly výběr těchto jmen kult P. Marie a sv. Josefa, jména nových světců a fakt, že mnohá z nich volili i Habsburkové (Josef II., Marie Terezie, Karel VI. atd.), ovšem antroponyma užívaná v 17. století se uplatňovala nadále.

\section{OBDOBÍ 1786-1945}

Během tohoto rozsáhlého období prošly české země složitým hospodářským, politickým a společenským vývojem (podrobněji např. Bělina/Rak 1992: 11-101; Pleskalová 2011: 134-138). Do r. 1945 žili Češi a Němci v těsném kontaktu, který byl upevňován četnými smíšenými sňatky. Tyto skutečnosti se odrazily i v antroponymii českých zemí (Beneš 1998: 52-58). Obě etnika spojovalo dvoučlenné oficiální pojmenování, které bylo závazné pro všechny obyvatele včetně žen a dětí (Antonín Kmoch, Marie Löschnerová), a zpočátku též společný základní repertoár křestních jmen, v němž zaujímala přední místo jména barokní a který obsahoval širokou škálu křestních jmen užívaných v 17. - 18. století. V 19. století sice obě etnika nadále preferovala barokní jména, ale v ostatních jménech se začala od sebe odlišovat. Od počátku českého národního obrození (1770) pronikala do repertoáru křestních jmen Čechů stále častěji jména slovanského původu jako výraz národního uvědomění (Jaroslav, Bohumil, Božena), zatímco Němci užívali mnohem častěji než Češi četná jména původu německého (Wilhelm, Rudolf, Adolf). S postupným prosazováním češtiny do různých oblastí veřejného života vzrůstala u Čechů obliba jmen slovanských a jména německého původu pozvolna ustupovala do pozadí. Vznik samostatného českého státu v r. 1918 pozici češtiny významně posílil a díky prestiži národního jazyka přečkala čeština období německé okupace (1939-1945) beze škod. Ovšem v těchto pro Čechy těžkých dobách popularita německých křestních jmen klesala a v r. 1945 zanikla zcela. Těsné česko-německé kontakty skončily v roce 1945 vyhoštěním Němců z ČR. Negativní postoj k německým jménům sice postupně slábl, ale ani v druhé polovině 20. století nebyla $\mathrm{v}$ ČR německá jména častá. Většinou se udržovala v důsledku rodinné tradice (otec a syn mají jméno Karel).

11 Oblíbenost zde uvedených jmen potvrzuje řada dalších studií a monografií, např. Beneš (1998) nebo diplomové práce věnované analýze antroponym doložených v některém ze soudobých historických pramenů, např. Rozprýmová (2007) nebo Kloudová (2011); podrobněji Pleskalová (2011: 96). 
Naše tvrzení dokládá následující antroponymický materiál z českých zemí. V letech 1786-1840 patřila podle Šmilauera (1950: 174-175) k nejužívanějších jménům v českých zemích antroponyma Josef, Jan, František, Václav, Antonín, Anna, Marie, Barbora, Kateřina, Františka. V období 1840-1900 obliba barokních jmen trvá, ale zároveň se u Čechů začínají prosazovat také jména národní. Z mužských jmen se vedle jména Václav často uplatňují Jaroslav, Ladislav, Miroslav, Vladimír, Zdeněk. Podle pražských adresářů z let 1859, 1896 patří mezi pět nejužívanějších jmen českých obyvatel Josef, Jan, František, Václav, Antonín (Šmilauer 1974: 25). Doskočil (1941: 25) potvrdil vysokou oblibu těchto mužských jmen a připojil pět nejoblíbenějších jmen ženských, a to Marie, Františka, Josefka, Antonie, Teresie, zatímco předtím hojně užívaná jména Kateřina, Dorota, Barbora v polovině 19. století ustupovala. Bohuš $(2011: 109,118)$ ukázal, že němečtí obyvatelé Olomouce upřednostňovali jednak jména barokní, jednak jména německého původu. Uvádí pořadí prvních patnácti mužských i ženských jmen doložených k r. 1880: Josef, Johan, Franz, Karl, Anton, Wilhelm, méně častá Rudolf, Alois, Eduard, Adolf, Julius, Ferdinand, Heinrich, Leopold, Moritz; Marie, Anna, Theresia, Francisca, Josefa, Antonia, méně častá Emilie, Julie, Katharina, Johanna, Josefine, Rosa, Aloisie, Wilhelmine, Hermine. Pro období 1901-1950 jsou přesvědčivé dva důkazy: Šmilauer (1974: 25-26) představil na základě jmen v pražském adresáři z let 1937-1938 nejužívanější křestní jména té doby: Josef, František, Václav, Antonín, Karel; Marie, Anna, Božena, Františka, Josefa. Puš (2010: př́loha) uvádí křestní jména užívaná v Olomouci k r. 1910: nejčetnější jsou Josef, Johan, poměrně častá Karl, Rudolf, Franc, méně častá Alois, Adolf, Otto, Anton, Eduard atd.; nejvíce se uplatnila jména Marie, Anna, ostatní byla - vzhledem k bohatě zastoupeným prvním dvěma jménům - spíše ojedinělá: Josefine, Theresie, Emilie, Franziska, Rosa atd.

Diachronní pohled na česko-německé vztahy s ohledem na antroponymii českých zemí odhalil jejich nejzávažnější důsledky ve sfére antroponym. 1) Společný základní repertoár křestních jmen, v němž zaujímala významné místo jednak církevní jména (např. Johannes/Johann/Jan), jednak jména německá (např. Henricus/Heinrich), u česky mluvících obyvatel hojně užívaná do konce 18 . stol. Naopak v německém prostředí byla akceptována - ovšem jen v malé míře - nejvýznamnější církevní jména česká (Václav/Wenzel, Ludmila, Vojtěch). 2. Vyspělejší způsob identifikace osoby pomocí dvoučlenného jména (Franz Schuster), preferovaný německy mluvícími obyvateli již od 14. stol., podpořil a zároveň uspíšil zavádění dvoujmennosti v českém prostředí (Jiřik Kohout).

\section{Prameny}

HORČIČKA, Adalbert (ed.) (1896) Urkundenbuch der Stadt Aussig bis zum Jahre 1526. Prag: in Comission bei H. Dominicus Buchhandlung.

MÜLLER, Aug. (ed.) (1929) Quellen- und Urkundenbuch des Bezirkes TeplitzSchönau bis zum Jahre 1500. Prag: Druck und Verlagsanstalt, Ges. M. B. H., Teplitz-Schönau. 
SCHLESINGER, Ludwig (ed.) (1892) Urkundenbuch der Stadt Saaz bis zum Jahre 1526. Leipzig und Wien: in Comission bei F. A. Brockhaus.

\section{Literatura}

BĚLINA, Pavel/Jiř́ Rak et al. (1992) Dějiny zemi Koruny české II. Praha: Paseka.

BENEŠ, Josef (1998) Německá př́jmení u Čechů I, II. Ústí na Labem: Univerzita J. E. Purkyně v Ústí nad Labem.

BOHUŠ, Marek (2011) Deutsche Personennamen in Olomouc im Jahre 1880. Olomouc: Disertační práce, FF Univerzity Palackého v Olomouci.

DOSKOČIL, Karel (1941) „Náčrt dějin českých jmen křestních.“ In: Václav Davídek/ Karel Doskočil et al., Česká jména osobní a rodová. Praha: Rodopisná společnost, 49-69.

HOLÁ, Pavla (2009) „Křestní jména na Klatovsku v 18. století.“ Acta onomastica 50, 189-195.

KLOUDOVÁ, Martina (2011) Antroponyma v matrice farního úr̆adu Horní Branná (1661-1666). Brno: Magisterská diplomová práce, FF Masarykovy univerzity Brno.

PLESKALOVÁ, Jana (2011) Vývoj vlastních jmen osobnich v českých zemích v letech 1000-2010. Brno: Host, Masarykova univerzita.

PUŠ, Ivan (2010) Olmützer Volkszählungslisten vom Jahre 1910 als Quelle der Vornamen. Ein Beitrag zur Analyse der Vornamen der deutschen Bürger in der Stadt Olmütz. Olomouc: Bakalářská diplomová práce, FF Univerzity Palackého v Olomouci.

RADA, Ivan/Vratislav VANÍČEK et al. (1992) Dějiny zemí Koruny české. I. Praha: Paseka.

ROZPRÝMOVÁ, Jitka (2007) Antroponyma v chrlickém lánovém rejstřiku (1674). Brno: Magisterská diplomová práce, FF Masarykovy univerzity Brno.

SPÁČILOVÁ, Libuše (2004) „Das älteste Olmützer Stadtbuch als anthroponymische Quelle.“ In: H. J. Behr/I. Lisový et al. (eds.), Deutschböhmische Literaturbeziehungen. Germano-Bohemica. Hamburg: Verlag Dr. Kovač, 287-306.

SPÁČILOVÁ, Libuše (2011a) „Weibliche Namen in der Stadt Olmütz bis 1650.“ In: I. Fiala-Fürst/J. Čmero (eds.), Amici amico III. Olomouc: Univerzita Palackého v Olomouci, 421-434.

SPÁČILOVÁ, Libuše (2011b) „Mänliche Rufnamen in der Stadt Olmütz bis 1650.“ In: M. Kováčová/J. Meier et al. (eds.), Deutschslawische Kontakte - Geschichte und Kultur. Košice: Filozofická fakulta UPJŠ v Košiciach, 95-114.

ŠMILAUER, Vladimír (1950) „Křestní jména v Sobotce 1780-1848.“ Časopis pro moderní filologii 33/4, 174-175.

ŠMILAUER, Vladimír (1974) „Úvodem.“ In: František Kopečný, Průvodce našimi jmény. Praha: ČSAV, 9-29. 


\section{Resumé \\ ČESKO-NĚMECKÉ KONTAKTY \\ VE SVĚTLE ANTROPONYMIE ČESKÝCH ZEMÍ}

Diachronní pohled na česko-německé vztahy s ohledem na antroponymii českých zemí odhalil jejich nejzávažnější důsledky ve sféře vlastních jmen osobních. 1) Byl to především společný základní repertoár křestních jmen, který se vytvářel v těsném kontaktu česky mluvících obyvatel s německými příchozími a pod sjednocujícím vlivem římskokatolické církve. V něm zaujímala významné místo jména církevní (napr. Jan/Johannes/Johann, Nicolaus/Mikuláš, Petr/Peter/Petrus, Margaretha/Markéta, Katharina/Kateřina) a jména německá (Henricus/Heinrich, Albertus/Albert/Albrecht, Ulricus/Ulrich), u česky mluvících obyvatel užívaná ve větší mírre jen do konce 18. stol. Naopak v německém prostředí byla akceptována - ovšem jen v malé míře - nejvýznamnější církevní jména česká (Václav/Wenzel, Ludmila, Vojtěch). 2. Vyspělejší způsob identifikace osoby pomocí dvoučlenného jména (křestní jméno + př́ijmí, později dědičné příjmení - Johannes Schwarz), který preferovalo německy mluvící obyvatelstvo českých zemí již od 14. stol., ovlivnil a zároveň uspíšil zavádění dvoujmennosti v českém prostředí (Jan Kohout), ovšem jen u mužských zástupců rodiny. - Tyto těsné českoněmecké kontakty skončily po druhé světové válce v r. 1945 vyhoštěním Němců z České republiky. Od té doby jsou v ČR křestní jména německého původu spíše ojedinělá, udržují se většinou jen rodinnou tradicí (otec Karel, syn Karel, podobně Jindřich, Oldřich a další).

Klíčová slova: antroponyma, čeština, němčina, kontakty

\section{Abstract \\ CZECH-GERMAN RELATIONSHIPS IN RELATION TO THE ANTHROPONYMY OF THE CZECH LANDS}

A diachronic analysis of Czech-German relationships in relation to the anthroponymy of the Czech lands has revealed that the most significant effect of the contact can be seen in the domain of personal names. First, a common inventory of Christian names formed as a result of the close contact of the Czech-speaking population with the newly arrived German-speaking population and under the unifying influence of the Roman Catholic church. Important parts of the inventory were formed by names relating to the church (e.g. Jan/Johannes/Johann, Nicolaus/Mikuláš, Petr/Peter/Petrus, Margaretha/ Markéta, Katharina/Kateřina) and by German names (Henricus/Heinrich, Albertus/ Albert/Albrecht, Ulricus/Ulrich), used more frequently by the Czech-speaking inhabitants only until the end of the $18^{\text {th }}$ century. On the other hand, the most significant Czech names related to the church were - although to a small extent - accepted within the German community (Václav/Wenzel, Ludmila, Vojtěch). Second, a more sophisticated way of identifying a person by using a two-element name (a Christian name and complementary anthroponym, later on a hereditary surname - Johannes Schwarz), 
preferred by the German speaking inhabitants of the Czech lands already since the $14^{\text {th }}$ century, influenced and also speeded up the introduction of the two-name system in Czech community (Jan Kohout), although only in the case of male representatives of families. The close Czech-German contacts ended after World War II in 1945 by the expulsion of Germans from the Czechoslovakia. Since then, names of German origin occur in the Czech Republic only scarcely, mostly as a family tradition (a father named Karel, a son named Karel, similarly Jindřich, Oldřich etc.).

Keywords: anthroponyms, Czech, German, contacts

\section{Povzetek \\ ČEŠKO-NEMŠKI STIKI V LUČI ANTROPONIMIJE ČEŠKIH DEŽEL}

Diahroni pogled na češko-nemške stike z ozirom na antroponimijo čeških dežel je razkril najpomembnejše ugotovitve na področju osebnih lastnih imen. 1. Predvsem je obstajal skupni osnovni nabor krstnih imen, ki se je izoblikoval v tesnem stiku češko govorečih prebivalcev z nemškimi prišleki in pod povezovalnim vplivom rimskokatoliške cerkve. V njem so zavzemala pomembno mesto cerkvena imena (npr. Jan/ Johannes/Johann, Nicolaus/Mikuláš, Petr/Peter/Petrus, Margaretha/Markéta, Katharina/Kateřina) in nemška imena (Henricus/Heinrich, Albertus/Albert/Albrecht, Ulricus/ Ulrich), ki so bila v rabi pri češko govorečih prebivalcih v večji meri le do konca 18. stol. Nasprotno so bila v nemškem okolju sprejeta - resda le v manjši meri - najpomembnejša češka cerkvena imena (Václav/Wenzel, Ludmila, Vojtěch). 2. Razvitejši način identifikacije oseb s pomočjo dvodelnega imena (krstno ime + vzdevek, pozneje dedni priimek - Johannes Schwarz), ki ga je najraje uporabljalo nemško govoreče prebivalstvo čeških dežel že od 14. stol., je vplival in obenem pospešil uvedbo dvoimenskosti v češkem okolju (Jan Kohout), resda le pri moških zastopnikih družine. - Ti tesni češko-nemški stiki so se končali po drugi svetovni vojni 1. 1945 z izgonom Nemcev iz Češke republike. Odtlej so v ČR krstna imena nemškega izvora le osamljena, ohranjajo se večinoma le z družinsko tradicijo (oče Karel, sin Karel, podobno Jindřich, Oldřich in druga).

Ključne besede: antroponimi, češčina, nemščina, stiki 